\title{
Corrigendum
}

\section{Corrigendum to “Biological Effects of Medicinal Plants on Induced Periodontitis: A Systematic Review"}

\author{
Jefferson Soares de Oliveira ${ }^{D}{ }^{1}$, Moara e Silva Conceição Pinto, ${ }^{2}$ \\ Lucas de Araújo de Bastos Santana ${ }^{(D)},{ }^{1}$ Antonione Santos Bezerra Pinto $\mathbb{D D}^{3},{ }^{3}$ \\ David di Lenardo, ${ }^{1}$ and Daniel Fernando Pereira Vasconcelos $\mathbb{D}^{2}$ \\ ${ }^{1}$ Laboratory of Biology and Biochemistry Plants (BIOqPLANT), Federal University of Piaui, Parnaiba, PI, Brazil \\ ${ }^{2}$ Laboratory of Histological Analysis and Prepare (LAPHIS), Federal University of Piaui, Parnaiba, PI, Brazil \\ ${ }^{3}$ Department of Morphology, LABICONTE, Federal University of Ceara, Fortaleza, CE, Brazil
}

Correspondence should be addressed to Daniel Fernando Pereira Vasconcelos; vasconcelos@ufpi.edu.br

Received 3 December 2017; Accepted 10 December 2017; Published 27 February 2018

Copyright (c) 2018 Jefferson Soares de Oliveira et al. This is an open access article distributed under the Creative Commons Attribution License, which permits unrestricted use, distribution, and reproduction in any medium, provided the original work is properly cited.

In the article titled "Biological Effects of Medicinal Plants on Induced Periodontitis: A Systematic Review" [1], it is stated in Table 1 that Hosadurga et al., cited as references 4 and 16 in the article, examined the anti-inflammatory action of $2 \%$ curcumin and Ocimum sanctum gel in a separate model. However, the authors of these articles informed us that they studied the gingival index, which is an indirect measure of inflammation in the gingival tissues. They also assessed the antimicrobial activity but did not publish the data, since they encountered a problem with the solubility and did not get a well-defined clear zone of inhibition. Corrected information about references [4] and [16] in Table 1 is as follows. 


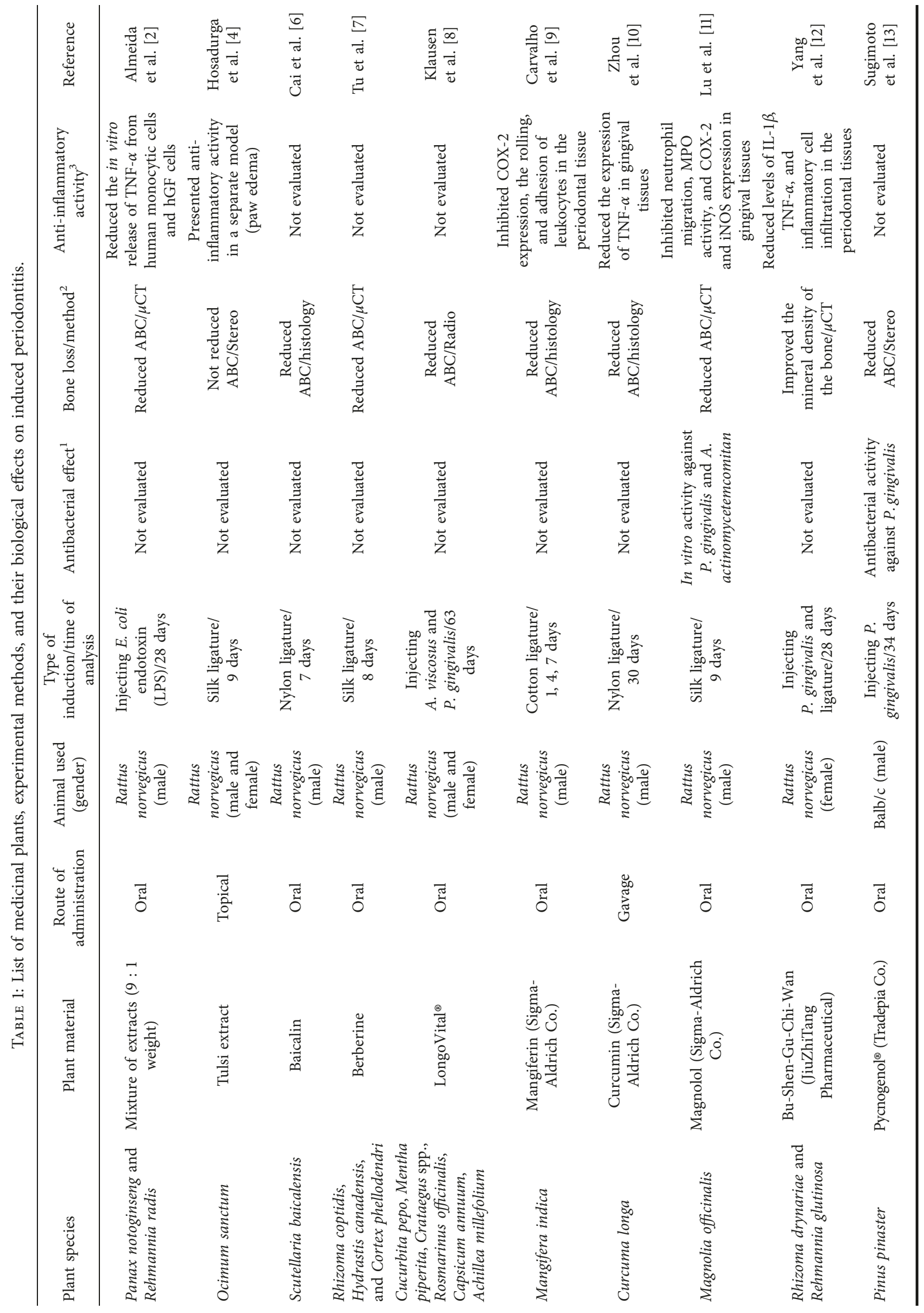




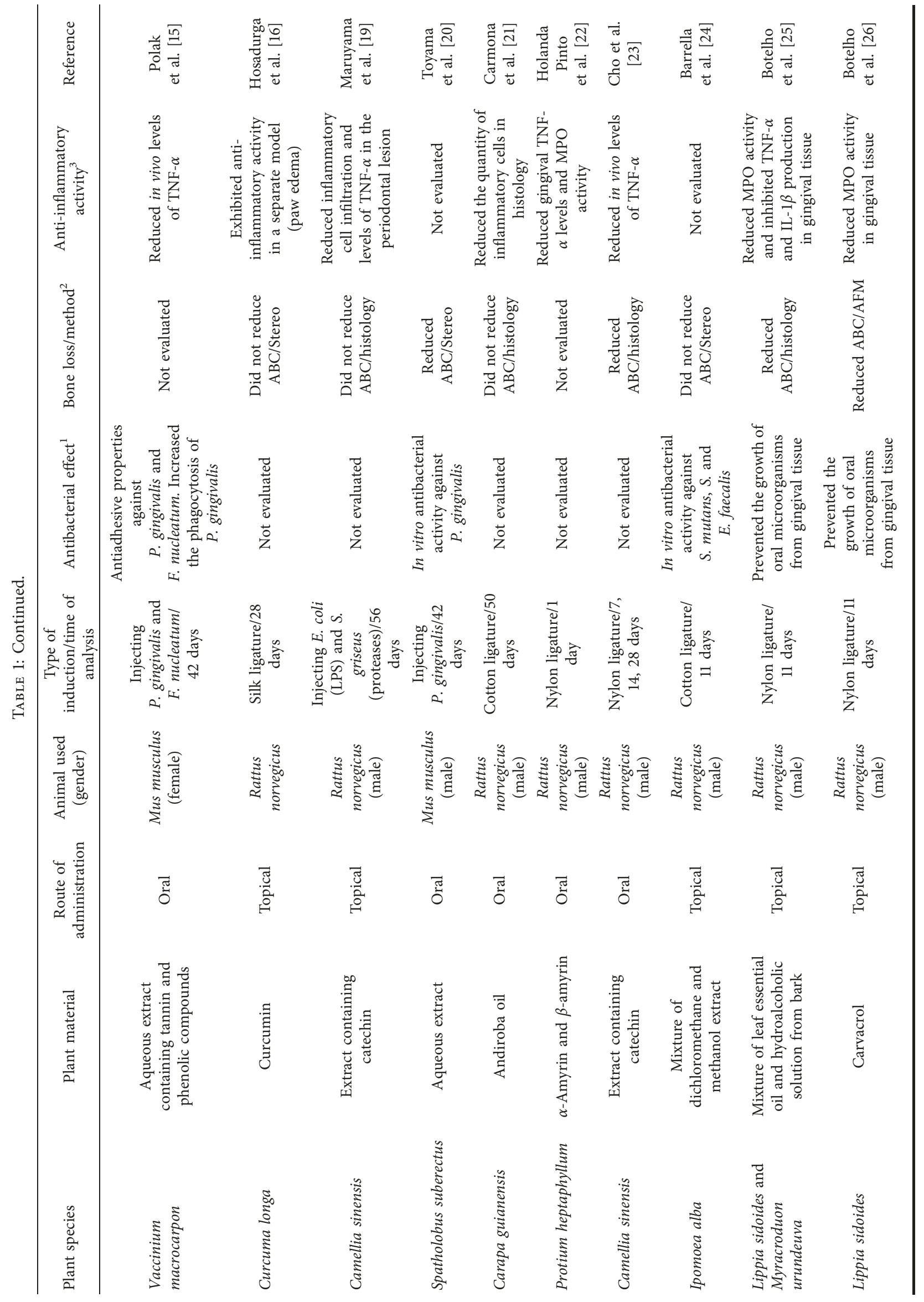




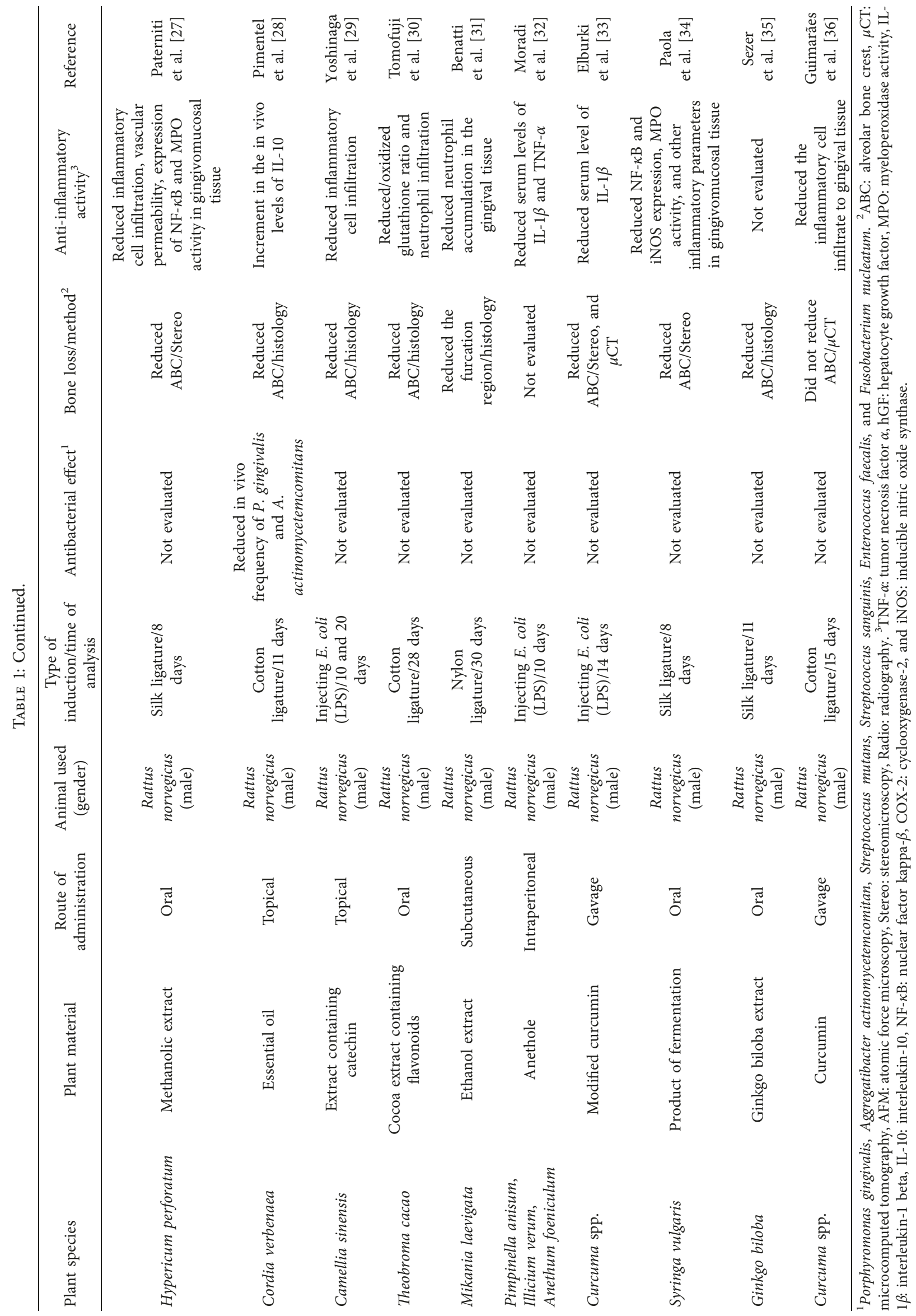




\section{References}

[1] J. Soares de Oliveira, M. S. Conceição Pinto, L. A. B. Santana, A. S. B. Pinto, D. Lenardo, and D. F. P. Vasconcelos, "Biological effects of medicinal plants on induced periodontitis: a systematic review," International Journal of Dentistry, vol. 2016, Article ID 3719879, 10 pages, 2016. 


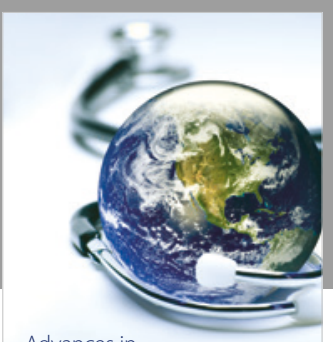

Advances in
Public Health

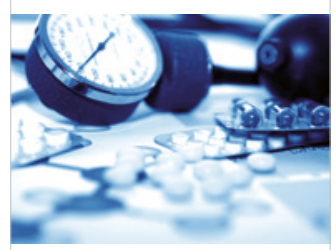

Case Reports in

Medicine

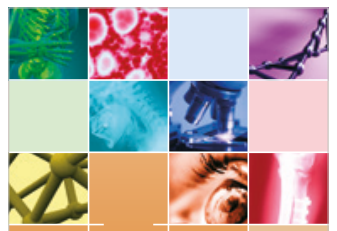

niernational Journal of

Biomaterials
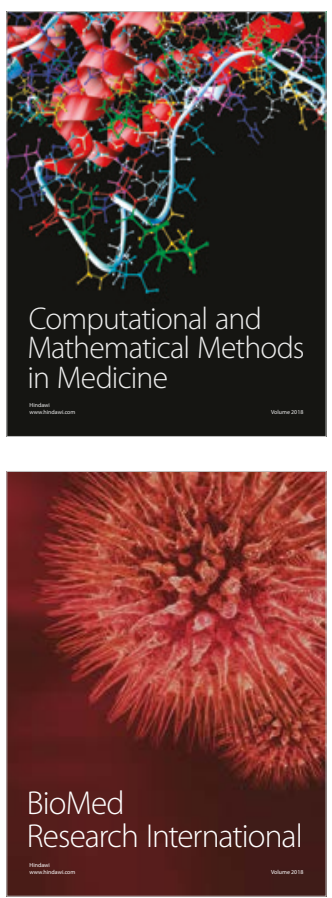

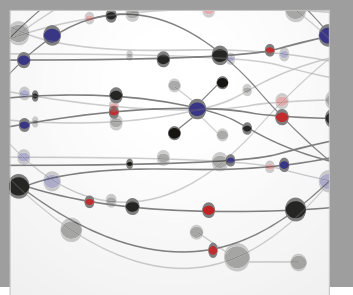

The Scientific World Journal Dentistry

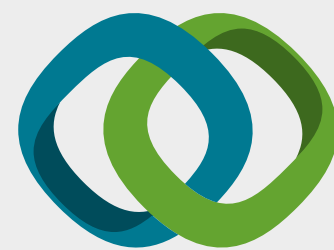

Hindawi

Submit your manuscripts at

www.hindawi.com
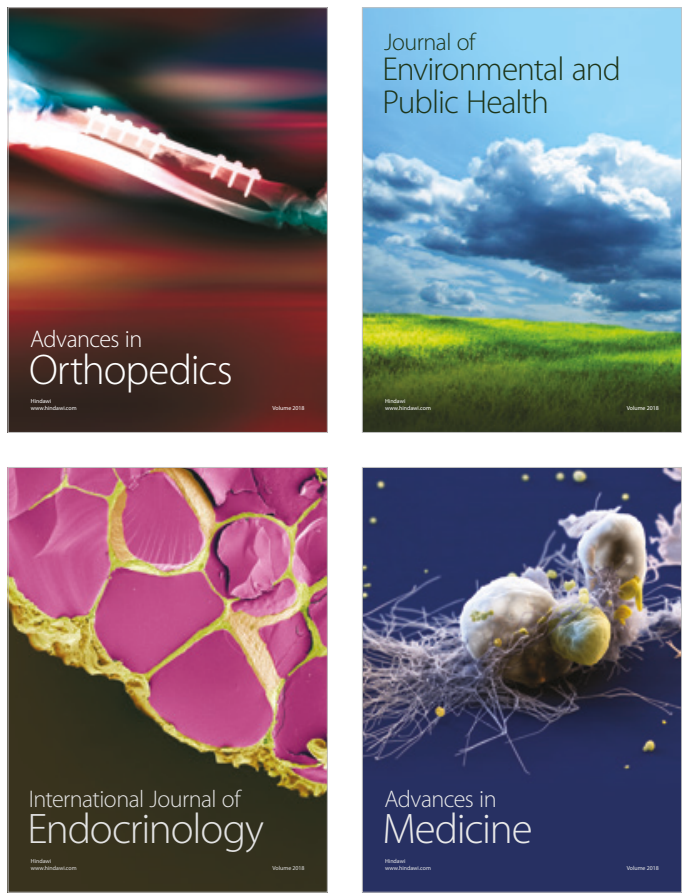
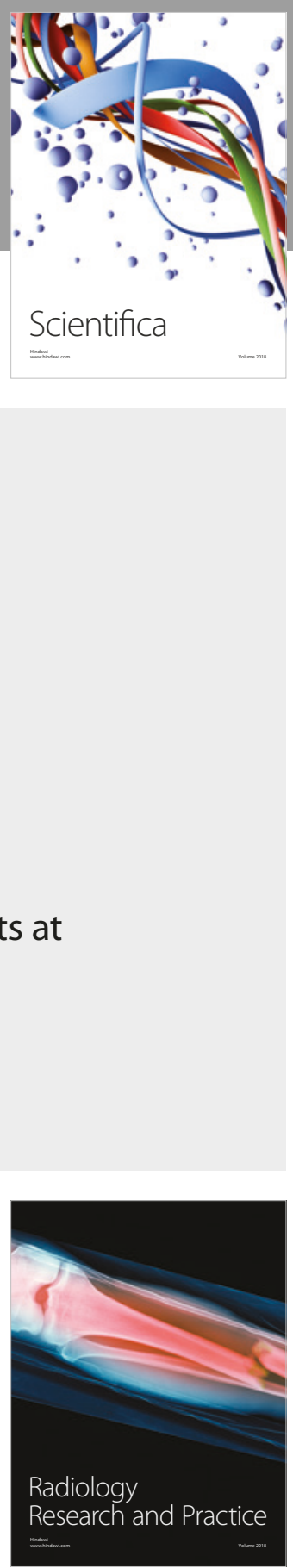

Scientifica

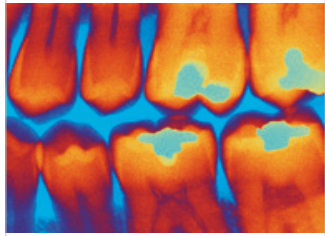

Case Reports in

Dentistry
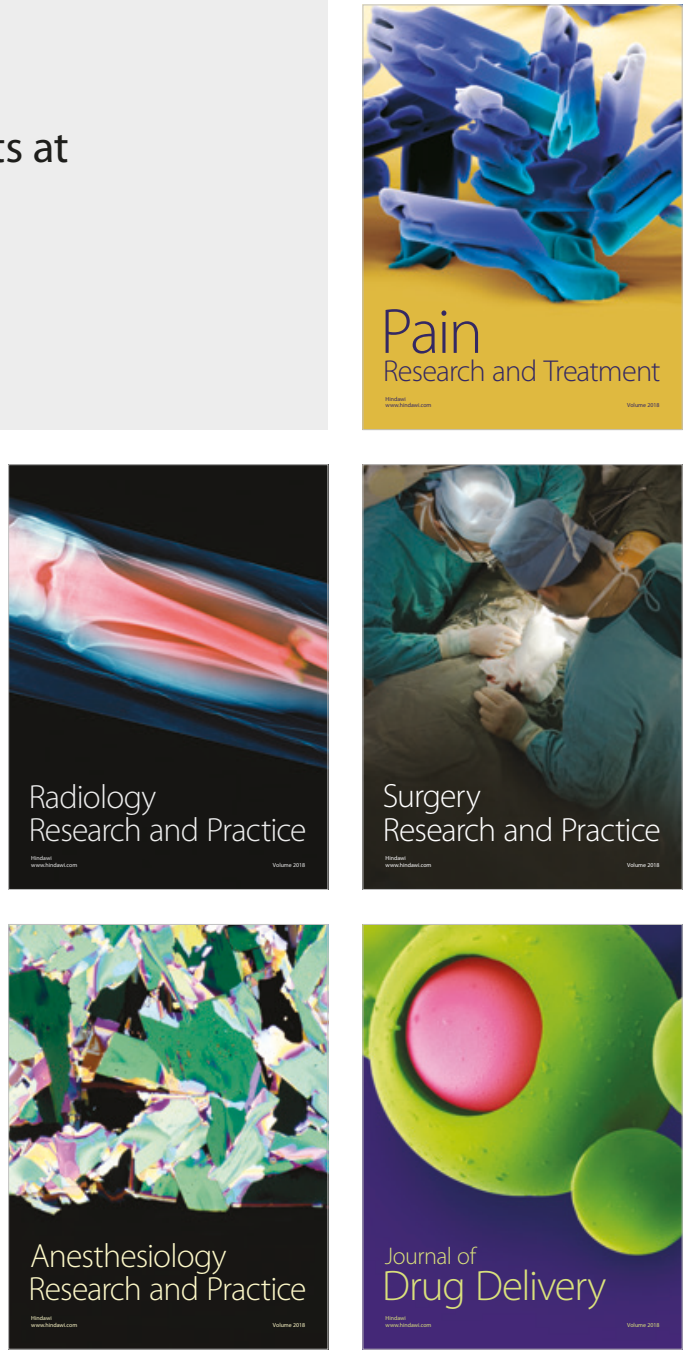